(Final Revision)

\title{
Modelling the Innovation Value Chain
}

\author{
Stephen Roper ${ }^{1}$, Jun $\mathrm{Du}^{2}$ and James H Love ${ }^{2}$ \\ ${ }^{1}$ Warwick Business School, University of Warwick, Coventry, CV4 7AL, UK. \\ Email: stephen.roper@,wbs.ac.uk \\ ${ }^{2}$ Economics and Strategy Group, Aston Business School, Aston University, \\ Birmingham, B4 7ET, UK \\ Email: j.du@aston.ac.uk; j.h.love@,aston.ac.uk
}

\begin{abstract}
Innovation events - the introduction of new products or processes - represent the end of a process of knowledge sourcing and transformation. They also represent the beginning of a process of exploitation which may result in an improvement in the performance of the innovating business. This recursive process of knowledge sourcing, transformation and exploitation comprises the innovation value chain. Modelling the innovation value chain for a large group of manufacturing firms in Ireland and Northern Ireland highlights the drivers of innovation, productivity and firm growth. In terms of knowledge sourcing, we find strong complementarity between horizontal, forwards, backwards, public and internal knowledge sourcing activities. Each of these forms of knowledge sourcing also makes a positive contribution to innovation in both products and processes although public knowledge sources have only an indirect effect on innovation outputs. In the exploitation phase, innovation in both products and processes contribute positively to company growth, with product innovation having a short-term 'disruption' effect on labour productivity. Modelling the complete innovation value chain highlights the structure and complexity of the process of translating knowledge into business value and emphasises the role of skills, capital investment and firms' other resources in the value creation process.
\end{abstract}

\section{Acknowledgements}

This research was undertaken as part of a project funded by the ESRC (Award RES-000-22-0729). We are grateful for constructive comments received during presentations of earlier versions of the paper at the following venues: Imperial College, London; Georgia Institute of Technology, Atlanta; the Economic and Social Research Institute, Dublin; the Office for National Statistics BDL Quarterly Workshop, London; and an ESRC Research Seminar at Durham University. We are particularly grateful for the detailed comments of Loles Añon, Paul Kattuman and three anonymous referees.

Keywords: Innovation; Productivity; Knowledge; Business Growth; Ireland 


\section{Modelling the Innovation Value Chain}

\section{Introduction}

An innovation event, such as the introduction of a new product or process, represents the end of a series of knowledge sourcing and translation activities by a firm. It also represents the beginning of a process of value creation which, subject to the firm's own attributes and market conditions, may result in an improvement in the performance of the innovating business. Knowledge or productivity spillovers may also then lead to improvements in the performance of other co-related or co-located firms (Klette et al., 2000; Beugelsdijck and Cornet, 2001). Here, however, following Crépon et al. (1998), Lööf and Heshmati (2001 and 2002) and Love and Roper (2001), our focus is on the gains from innovation to the innovating firm itself. Building explicitly on our earlier work on knowledge sourcing and innovation (Roper et al 2006), we are interested in modelling the recursive process through which firms source the knowledge they need to undertake innovation, transform this knowledge into new products and processes, and then exploit their innovations to generate added value. This process - which may involve feedback loops and external linkages comprises the Innovation Value Chain (IVC). Knowledge, of different types and from different sources, is the unifying factor providing the main operational link between the different elements of the innovation value chain. Competitive pressures and opportunities, however, provide the motivation for firms to engage in the risky, uncertain and costly activity which is innovation.

Our view of the IVC comprises three main links, beginning with firms' attempts to assemble the bundle of different types of knowledge necessary for innovation. This may involve firms' in-house R\&D activities alongside, and either complementing or substituting for, external knowledge sources (e.g. Pittaway et al., 2004). Cassiman and Veugelers (2002), for example, find evidence of a complementary relationship between firms' internal R\&D and their ability to benefit from external knowledge 
sources (see also Roper et al. 2006). Other studies, however, have identified a substitute relationship between internal knowledge investments and external knowledge sourcing (Schmidt 2005; Love and Roper 2001) As Guellec and van Pottelsberghe (2004) and Anselin et al. (1997, 2000) suggest, however, externally acquired knowledge is not homogenous and its complement or substitute relationship with in-house R\&D may depend on the type of external knowledge being considered.

Following firms' knowledge sourcing activity, the next link in the innovation value chain is the transformation of knowledge into physical innovation. We model this using the innovation production function approach (e.g. Geroski 1990; Harris and Trainor 1995; Love and Roper, 1999) which relates innovation outputs (i.e. new products or processes) to knowledge inputs. In the spirit of models of open innovation, however, we allow firms' innovation outputs to reflect both internally-generated knowledge - the result of in-house R\&D - and different types of knowledge sourced from external partners. The efficiency of the firm in translating this knowledge into product and process innovation is linked to the characteristics of the enterprise and its prior knowledge and managerial resources. Michie and Sheehan (2003), for example, suggest the importance of human resource management procedures for innovation, while Love et al. (2006) consider the beneficial effects for innovation of organisational factors such as cross-functional teams. The final link in the IVC relates to the exploitation of firms' innovations. This we model using an augmented production function approach (e.g. Geroski et al., 1993).

Our more detailed conceptual framework for the innovation value chain is outlined in Section 2, which also relates our notion of the innovation value chain to other theories of the firm and to our earlier analysis (Roper et al 2006). This emphasises the recursive nature of the causal process we envisage from knowledge sourcing to exploitation and describes in more detail our approach to estimating the different links in the innovation value chain. Section 3 describes our application of the innovation value chain model to data for manufacturing firms in Ireland and Northern Ireland. Section 4 reports the main empirical findings and Section 5 concludes with a brief 
review of the key empirical results and the policy and strategy implications. The main empirical innovation in the paper is the ability to identify the impact of different knowledge sources on business performance through the different links in the innovation value chain.

\section{Conceptual Foundations}

Our interest here is the process through which firms source, transform and exploit new - and potentially pre-existing - knowledge through innovation. At a fundamental level, this firm-specific process can be seen as part of a broader evolutionary dynamic in which product and process technologies are steadily refined and occasionally transformed (Nelson and Winter, 1962). Our empirical analysis, however, provides evidence of organisational learning, emphasising the Lamarkian rather than purely Darwinian character of technological development. It also emphasises the importance of the wider knowledge eco-system within which firms are operating, and the potential benefits of operating in an environment where there exist rich external knowledge sources and extensive networking opportunities (Iansiti and Levien, 2004). At the level of the firm, however, our analysis becomes more deterministic, relating innovation outputs and business performance to firms' knowledge and internal resources. In this sense at least our perspective is consistent with a resource-based or capabilities perspective on business growth and development (Foss, 2004).

Within this perspective, the first link in the innovation value chain is firms' knowledge sourcing activity, and we focus, in particular, on the factors which shape firms' engagement with particular knowledge sources. Here, in the literature we find a contrast in the relatively narrow perspective on knowledge acquisiton in some empirical studies of the innovation process, which regard in-house $R \& D$ as the only source of knowledge for innovation (e.g. Crépon et al.,1998; Lööf and Heshmati, 2001, 2002), and other studies which have placed increasing emphasis on different knowledge sources for innovation and the potential complementarities between them (see for example Veugelers and Cassiman,1999; Roper and Love, 2005). Building on our previous analysis (Roper et al 2006; Du et al 2007) we follow the latter 
approach, and identify five different types of knowledge sourcing activity which might shape firms' innovation: in-house R\&D (Shelanski and Klein, 1995); forward linkages to customers (Joshi and Sharma, 2004); backward links to either suppliers or external consultants (e.g. Horn, 2005; Smith and Tranfield, 2005); horizontal linkages to either competitors or through joint ventures (Hemphill, 2003; Link et al., 2005); and linkages to universities or other public research centres (Roper et al., 2004).

We also allow for potential complementarities or substitutabilities between firms' knowledge sourcing activities, and for the influence of firms' prior knowledge resources and knowledge utilisation capability on each knowledge sourcing activity. In particular, following the general argument in the literature on the resource-based view, we expect that the stronger are firms' in-house stocks of knowledge (e.g. enterprise size, foregn ownership, group membership) the less likely they are to need to engage in external knowledge sourcing (see also Schmidt, 2005). Similarly, we anticipate that firms are more likely to benefit from external knowledge sourcing - or be able to undertake such external knowledge sourcing at lower resource cost - where their knowledge utilisation capability is greatest ${ }^{1}$, as indicated both by the level of skills available at the plant and by the presence within the enterprise of a strong organisational capacity for undertaking R\&D. Public support for innovation or R\&D may also encourage external knowledge sourcing (Roper and Hewitt-Dundas, 2005; Link et al., 2005) ${ }^{2}$ as might a less buoyant market environment (Link et al., 2005) . $^{3}$ To summarise, the probability that a firm will engage in each of the five knowledge sourcing activities is given by:

\footnotetext{
${ }^{1}$ Others - notably Kim (1995) - have argued that both firms' prior knowledge base and knowledge acquisition capability are elements of absorptive capacity. Here, we differentiate between these two elements of this definition of absorptive capacity as we believe they may have different implications for knowledge sourcing activity.

${ }^{2}$ See Roper and Love (2005) for a detailed account of the development of innovation and R\&D policy in Ireland and Northern Ireland during the period covered by the analysis.

${ }^{3}$ Here, our data covers both Ireland - the Celtic Tiger - and Northern Ireland with the latter having experienced significantly slower growth rates during the 1990s. For example, average real GDP growth from 1991 to 2000 in Ireland was 7.1 per cent pa compared to 2.7 per cent pa in Northern Ireland. Sources: Ireland, GDP volume growth average measure, Table 13, Budgetary and Economic Statistics, March 2001, Department of Finance; Northern Ireland, NIERC/OEF Regional Economic Outlook, Spring 2001.
} 
$K S_{j i t}^{*}=\beta^{\prime} K S_{k i t}+\gamma_{0}^{\prime} R I_{j i t}+\gamma_{1}^{\prime} K U C_{j i t}+\gamma_{2}^{\prime} G O V T_{j i t}+\gamma_{3}^{\prime} M K T_{j i t}+\varepsilon_{j i t}$,

$K S_{j i t}=1$ if $K S_{j i t}^{*}>0 ; K S_{j i t}=0$ otherwise,

where; $K S_{j i t}$ stands for the $i^{\text {th }}$ firm's knowledge sourcing activity $j$ (or $k$ ) at time $t$, and $j, k=1,2,3,4,5, \quad i=1, \ldots \ldots, n ; t=1, \ldots \ldots, T$. The error term $\varepsilon_{j i t}$ is assumed to follow a multivariate normal distribution with mean zero and variance-covariance matrix $V$, where $V$ has values of 1 on the leading diagonal and $\rho_{\mathrm{jk}}=\rho_{\mathrm{kj}}$ for $\mathrm{j} \neq \mathrm{k}$. $K S_{k i t}$ represents the firm's other knowledge sourcing activities. If $\beta$ is positive this would suggest a complementary relationship between the firm's knowledge sourcing activities; negative $\beta$ would suggest a substitute relationship. $R I_{j i t}$ is a set of indicators of the firm's resource base and, as indicated earlier, we expect $\gamma_{0}$ to be negative. $K U C_{j i t}$ is a set of indicators intended to reflect the firm's knowledge utilisation capacity and $G O V T_{j i t}$ reflect access to government support for innovation and upgrading. Coefficients on both (i.e. $\gamma_{1}$ and $\gamma_{2}$ ) are expected to be positive. $M K T_{j i t}$ is intended to reflect the buoyancy of local markets, and following Link et al., (2005) we expect this to be negative.

To estimate the simultaneous knowledge sourcing equations (1), the most efficient approach from an econometric point of view is multivariate probit (MVP) although, as Greene (2005) notes, the efficiency gains from MVP are reduced where the vectors of independent variables are strongly correlated. Here, the anticipated determinants of each knowledge sharing activity are similar (as suggested by equation (1)) with the added potential for simultaneity between knowledge sourcing activities. Further difficulties also arise in the practical application of an MVP approach using our survey based data. First, adopting a simultaneous estimation approach exacerbates the loss of observations due to missing data in our sample, offsetting any gains in statistical efficiency. Second, in practice, achieving convergence with an MVP estimator places some limits on the degree of simultaneity which it is possible to include. In our model this is particularly undesirable because we are interested in the complementary or substitute relationship between knowledge sourcing activities.

Third, the derivation of marginal effects, which are important for our understanding of 
the innovation value chain, is less straightforward with MVP than with simpler modelling frameworks. Instead of using MVP (on which see Roper et al., 2006) we therefore prefer to adopt a simpler approach using five single equation probit models. This approach, while sacrificing some statistical efficiency, provides substantial gains in terms of the number of observations used, our ability to reflect more fully the relationship between knowledge sourcing activities and our ability to identify readily interpretable marginal effects.

The second link in the innovation value chain is the process of knowledge transformation, in which knowledge sourced by the enterprise is translated into innovation outputs. This is modelled using an innovation or knowledge production function (e.g. Geroski 1990; Harris and Trainor 1995) in which the effectiveness of a firm's knowledge transformation activities is influenced by enterprise characteristics, the strength of the firm's resource-base, as well as the firm's managerial and organisational capabilities (Griliches, 1992; Love and Roper, 1999). In terms of innovation outputs, we follow the suggestion of Pittaway et al. (2004) who emphasise the importance of examining both product and process innovation, and we anticipate that knowledge from different sources may have differential product and process effects. Joshi and Sharma (2004), for example, suggest the importance of knowledge of customers' preferences in shaping firms' innovation success, while Roper et al. (2006) emphasise the greater value of backwards and horizontal knowledge linkages for process change. This suggests the possibility of different routes through which knowledge of different types might influence different aspects of firms' innovation activity and hence business performance. In general terms we write the innovation production function as:

$$
I_{i t}=\phi_{0}^{\prime} K S_{k i t}+\phi_{1} R I_{i t}+\phi_{2} K U C_{i t}+\phi_{3} G O V T_{i t}+\phi_{4} M K T_{i t}+\varepsilon_{i t}
$$

Where $\mathrm{I}_{\mathrm{it}}$ is an innovation output indicator, $\mathrm{k}=1, \ldots, 5$, indicate the alternative knowledge sources identified earlier, $\varepsilon_{\mathrm{it}}$ is the error term and other variable definitions 
are as above.

In the innovation production function (equation (2)), however, we have different sign expectations for some of the independent variables from that in the knowledge sourcing equations (equation (1)). Where firms' internal resources are strong, for example, we would expect this to contribute positively to the efficiency with which firms develop new innovations but to discourage knowledge sourcing (e.g. Crépon et al., 1998; Lööf and Heshmati, 2001 and 2002). However, as in the knowledge sourcing models, we expect firms' innovation outputs to be positively related to knowledge utilisation capacity (e.g. Griffith et al., 2003). Government assistance we would regard as contributing to, or augmenting, the firm's resource base and would therefore anticipate positive coefficients (e.g. Roper and Hewitt-Dundas, 2005; Link et al., 2005). We also include in the innovation production function locational indicators for whether an establishment is in Ireland or Northern Ireland designed to reflect the legislative and economic environment within which firms are operating. Ceteris paribus, a more restrictive regulatory environment, for example, might restrict firms' ability to generate new innovation.

The appropriate estimation method for the innovation production function depends primarily on the nature of the dependent variable. Binary indicators for product or process innovation suggest simple bivariate probit models, while innovation success (i.e. the percentage of sales derived from new products) has both upper and lower bounds and suggests a Tobit model. A potential issue at this stage of the innovation value chain, however, is selectivity bias (e.g. Lööf and Heshmati, 2002). In the innovation production function this may arise from two main sources. First, the group of innovating firms may be self-selecting in some sense, inducing a bias between the expected values of the parameters of the estimated innovation production function and the data generating mechanism for the population as a whole. Or, due to sample design, non-response, or survey methodology, the selected sample may be atypical in some way of the underlying population. A consistent estimator for this type of model 
given standard normality assumptions is the two-stage procedure outlined in Heckman (1979). This involves the estimation of a Probit model to estimate the selection mechanism and the incorporation of a selection parameter in the innovation production function (see Greene, 2005, p. 639 for details). An alternative, more efficient, approach is to use a maximum likelihood estimator for business performance allowing for sample selection. Practical application of both approaches, however, raises issues of identification requiring, ideally, some distinction between the set of variables included in the selection equation and the innovation production function (see Maddala, 1973, p. 271; Cosh et al., 1997). Elsewhere (i.e. Love et al., 2006), we have explored the potential importance of selection bias in the innovation decision using the current dataset. This provided reassuring results, suggesting little evidence of any significant selection bias in the innovation decision, perhaps due to the broadly-based and nationally representative sampling approach used in our survey data and the particular questioning approach adopted ${ }^{4}$. In the estimation of equation (2) reported here we therefore base our analysis on standard econometric approaches, although for comparison we also report additional estimates of equation (2) for innovation success based on the sample of product innovators only (i.e. excluding the lower limit value $)^{5}$.

The final link in the innovation value chain is knowledge exploitation, i.e. the process by which enterprise performance is influenced by innovation (Geroski et al., 1993). At this point we envisage that firms' acquired knowledge has been codified into specific product or process innovations captured in our innovation output variables. It is therefore these variables, which represent new market offerings, that might drive enhanced business performance, and which provide the link between firms' knowledge sourcing activities and performance. The strength of this linkage, however,

\footnotetext{
${ }^{4}$ Non-response surveys conducted after each main survey suggested little evidence of any systematic difference in innovation behaviours between respondents and non-respondents (e.g. Roper and Hewitt-Dundas, 1998, Annex 1). Question non-response was also relatively limited. For example, 91 per cent of respondents indicating they were product innovators (binary response) also provided information on the extent of their innovation activity. 5 Another potential issue is multi-collinearity between the knowledge sourcing variables themselves and other elements of the innovation production function (compare equations (1) and (2), for example). In practice, however, we find something of an empirical separation between the two models with different factors determining firms' knowledge sourcing and knowledge transformation (compare Tables 2 and 3). In practice this should minimise any multicollinarity issues.
} 
will depend on firms' ability to appropriate the full market rent from their innovations.

To model this effect we use an augmented production function including the innovation output measures on the right hand side. Firms' market position and the strength of their internal resource base are used to capture the ability to appropriate post-innovation returns. In terms of the recursive innovation value chain, we regard the innovation output indicators as necessarily predetermined before the exploitation process which may lead to improvements in business performance. The augmented production function is expressed as:

$$
B P E R F_{i t}=\lambda_{0}+\lambda_{1} I N N O_{i t}+\lambda_{2} X_{i}+\lambda_{3} M K T_{i t}+\tau_{i}
$$

Where $B P E R F_{i}$ is an indicator of business performance (e.g. labour productivity or value-added per employee, sales growth or employment growth), INNO $i$ is a vector including innovation outputs measures for both process and product innovation, $\mathrm{X}_{\mathrm{i}}$ is a set of enterprise specific variables that are hypothesized to affect enterprise performance, and $M K T_{i}$ is a set of market environment indicators.

Two main econometric issues arise in operationalising equation (3): heterogeneity in performance outcomes and potential endogeneity of the innovation output measures. In terms of heterogeneity, it is clear that very large variations can exist in business performance even in narrowly defined industries (see Caves, 1998 for a survey; and on innovation behaviour see Lööf and Heshmati, 2002). To counter the bias introduced by potential outliers we here adopt robust regression approaches to the estimation of the augmented production function (Rousseeuw and Leroy, 1987; Koenker and Bassett, 1978). The potential endogeneity of innovation output measures in models of business performance has been discussed extensively in the literature, and a range of potential approaches have been adopted including two-stage estimation methods (e.g. Crépon et al, 1998) and the simultaneous estimation of the innovation and augmented production functions (e.g. Lööf and Heshmati, 2002). In conceptual terms, however, the recursive nature of the innovation value chain suggests that 
innovation output measures are necessarily predetermined prior to exploitation; in other words the innovation cannot be exploited until it has been introduced.

\section{Data $^{6}$}

Our empirical analysis is based on data from the Irish Innovation Panel (IIP) which provides information on the innovation, technology adoption, networking and performance of manufacturing plants throughout Ireland and Northern Ireland over the period 1991-2002. The IIP comprises four linked surveys conducted using similar postal survey methodologies, sampling frames provided by the economic development agencies in Ireland and Northern Ireland, and questionnaires with common questions. Each survey covers the innovation activities of manufacturing plants with 10 or more employees over a three year period with an average survey response rate of 34.5 per cent $^{7}$. The resulting panel is highly unbalanced with the 1775 observations used in the knowledge sourcing models, for example, covering 1393 individual establishments.

Innovation in the IIP is represented by three main variables. First, the proportion of total sales (at the end of each three year period) derived from products newly introduced during the previous three years. This variable - "innovation success" reflects not only firms' ability to introduce new products to the market but also their short-term commercial success. On average, 15.1 per cent of firms' sales were derived from new products across the IIP (Table 1). The second innovation output measure is a binary indicator of product innovation which reflects the extent of product innovation within the target population. The third innovation output measure is a similar binary indicator of process innovation, an indication of the extent of process innovation within the target population ${ }^{8}$. Over the whole sample, 62.5 per cent of firms were product innovators while 59.2 per cent were process innovators (Table 1).

\footnotetext{
${ }^{6}$ This section closely follows Roper et al (2006), which also contains a fuller description of the IIP surveys.

${ }^{7}$ Details of each wave of the survey can be found in Roper et al. (1996), Roper and Hewitt-Dundas (1998), Roper and Anderson (2000), Roper et al., (2004).

${ }^{8}$ For this variable a product (process) innovator was defined as an establishment which had introduced any new or improved product (process) during the previous three years.
} 
Notably, however, the overlap between the group of product and process innovators was not complete: around 70.2 per cent of product innovators were also process innovators, with 75.3 per cent of process innovators also being product innovators.

Across the panel, the most common form of knowledge sourcing was in-house R\&D, being undertaken by 48.2 per cent of establishments (Table 1). In terms of firms' external knowledge sourcing activities the IIP, like other innovation surveys, suggests that linkages along the supply chain are most common as part of firms' innovation activity: backward linkages (32.5 per cent) were most common followed by forward linkages (26.5 per cent). Horizontal linkages (12.1 per cent) and links to public knowledge sources (19.3 per cent), were less common but still formed a potentially important part of the knowledge sourcing strategies of a significant proportion of enterprises.

Our resource indicators are intended to give an indication of the strength of firms' in-house resource base, and its potential impact on knowledge sourcing and innovation. We also allow for the possibility that intra-group knowledge flows may enhance firms' own in-house resources, an issue of particular importance in Ireland (Buckley and Carter, 1999; Love and Roper, 2001). We therefore include variables which might give a quantitative indication of the scale of firms' resources - e.g. plant size, finance constraints - as well as other factors which might suggest the quality of firms' in-house knowledge base - e.g. multi-nationality, plant age, and production type. Multi-nationality is included here to reflect the potential for intra-firm knowledge transfer between national markets and plants, while plant age is intended to reflect the potential for cumulative accumulation of knowledge capital by older establishments (Klette and Johansen, 1998), or plant life-cycle effects (Atkeson and Kehoe, 2005).

Firms' knowledge utilisation capacity may reflect both the quality of human resource (Freel, 2005) as well as the organisational characteristics of the enterprise (Finegold and Wagner, 1998). In the models we therefore include indicators designed to reflect 
firms' skills base - the proportion of employees with graduate level qualifications and no qualifications - and whether the plant has a formal R\&D department ${ }^{9}$.

Literature on publicly funded R\&D has suggested repeatedly, since Griliches (1995), that government support for R\&D and innovation can have positive benefits for firms' innovation activity both by boosting levels of investment and through its positive effect on organisational capabilities (e.g. Buisseret et al., 1995) ${ }^{10}$. Arguably, this is particularly important in Ireland and Northern Ireland, which during much of the period covered by the IIP enjoyed EU Objective 1 status which provided resources for substantial investments in developing innovation and R\&D capability (Meehan, 2000; O’Malley et al., 2008). Indeed, over the sample period we find around a quarter of businesses receiving assistance for innovation, capital investment and/or training during each three year period (Table 1). Finally, to reflect potential differences in the operating environment between Ireland and Northern Ireland we include a locational dummy, and a variable designed to capture any perceived barriers to innovation due to regulatory or legislative requirements ${ }^{11}$.

\section{Empirical Analysis}

The complete innovation value chain model is given by equations (1) to (3) below:

$$
\begin{aligned}
& K S_{j i t}^{*}=\beta^{\prime} K S_{k i t}+\gamma_{0}^{\prime} R I_{j i t}+\gamma_{1}^{\prime} K U C_{j i t}+\gamma_{2}^{\prime} G O V T_{j i t}+\gamma_{3}^{\prime} M K T_{j i t}+\varepsilon_{j i t}, \quad \mathrm{j}, \mathrm{k}=1,5 \\
& K S_{j i t}=1 \text { if } K S_{j i t}^{*}>0 ; K S_{j i t}=0 \text { otherwise, } \\
& I_{i t}=\phi_{0}^{\prime} K S_{k i t}+\phi_{1} R I_{i t}+\phi_{2} K U C_{i t}+\phi_{3} G O V T_{i t}+\phi_{4} M K T_{i t}+\varepsilon_{i t} \\
& B P E R F_{i}=\lambda_{0}+\lambda_{1} I N N O_{i}+\lambda_{2} X_{i}+\lambda_{3} M K T_{i}+\tau_{i}
\end{aligned}
$$

\footnotetext{
9 Just under half of the plants which carried out in-house R\&D did so using a formal R\&D facility (Table 1). 10 Trajtenberg (2001), for example, offers more direct evidence on the links between public R\&D support and firms' proprietary knowledge base. In his examination of government support for commercial R\&D in Israel operated by the Office of the Chief Scientist (OCS), he concludes that 'industrial R\&D expenditures are closely linked (with a reasonable lag) to patents, and so are R\&D grants awarded by the OCS'.

${ }^{11}$ This derived from a question asking respondents to rank the importance on a Likert scale of regulatory or legislative requirements as a barrier to innovation.
} 
Discussion of our empirical results follows the recursive structure of the innovation value chain model. Enterprises' knowledge sourcing activities are explored in Section 4.1; Section 4.2 then deals with the innovation production function and considers the determinants of enterprises' decision to innovate and their innovation success. Finally, Section 4.3 focuses on the exploitation link of the innovation value chain. All estimations also include 2-digit industry dummy variables, results of which are not shown in order to save space. A key focus throughout our analysis is the marginal effects of knowledge sourcing and innovation which determine the strength of the links in the innovation value chain.

\subsection{Knowledge Sourcing}

The initial link in the innovation value chain is enterprises' knowledge sourcing activity. Bivariate probit models for each of the knowledge sourcing activities are reported in Table 2 based on a pooled sample from the IIP. Two issues are of particular interest here: first, what pattern of complementarity or substitutability exists between enterprises' knowledge sourcing activity; and, secondly, what other factors determine enterprises' knowledge sourcing behaviour.

In terms of potential complementarity or substitutability between knowledge sourcing activities, we find strongly significant and positive associations between in-plant R\&D and backward knowledge sourcing and public knowledge sourcing. These are illustrated in Figure 1 where each arrow represents a significant (complementary) link between alternative forms of knowledge sourcing activity. For example, there is a complementary relationship between internal knowledge generation (i.e. in-plant R\&D) and some external knowledge sourcing, supporting the results of Cassiman and Veugelers (2002) but running contrary to the results of Schmidt (2005) and Love and Roper (2001) which both suggest a substitution relationship between internal R\&D activity and external knowledge sourcing (see also Irwin and Klenow, 1996). Our results on the complementarity of internal and external knowledge sourcing also provide support for the importance of firms' knowledge utilisation capacity at the 
micro-level, reinforcing similar evidence from macro-economic studies (e.g. Griffith et al., 2003; Guellec and van Pottelsberghe, 2004). We also find strong evidence of complementarity between different external knowledge sourcing activities, with forward and backward knowledge sourcing and backward and public knowledge sourcing being particularly strongly linked (Table 2). One possible explanation is that enterprises are obtaining economies of scope as they learn to manage external relationships effectively and so benefit more from extending the range of their external knowledge sourcing activities.

In terms of the determinants of knowledge sourcing, our results provide limited support for the argument that firms' knowledge sourcing strategies are linked to the strength of their internal resource-base (Schmidt, 2005). For example, we find a non-linear relationship between plant size and all knowledge sourcing activities except public knowledge sourcing. For in-plant R\&D and forward knowledge sourcing (which have little direct linkage - Table 2), the relationship takes an inverted U-shape suggesting the probability of knowledge sourcing increases with scale below the turning point at 240-280 employees. Conversely, the probability of engaging in backward and horizontal knowledge sourcing decreases with scale until the turning point (180 employees in the case of backward knowledge sourcing and 230 employees in the case of horizontal) before increasing again. In substantive terms this suggests that smaller firms are more likely to engage in horizontal or backward knowledge sourcing but less likely to engage in forward knowledge sourcing or in-plant $R \& D$, a situation which is reversed above the turning points. In more methodological terms, the different impacts of the scale of the enterprise on the probability of each knowledge sourcing activity, a point echoed in Schmidt (2005), emphasises the importance of the disaggregated approach adopted here.

Other resource indicators prove of less general importance but do suggest some important relationships between enterprise characteristics and their knowledge sourcing activities. Multinational firms, for example, are less likely ceteris paribus to be undertaking in-house R\&D in our sample, but more likely to be undertaking 
knowledge sourcing from public sector organisations. This type of linkage may reflect recent suggestions about technology sourcing, where multinational firms invest in certain locations to access technology that is generated by host country firms or universities (Driffield and Love, 2005) ${ }^{12}$. Firms experiencing financial constraints were also more likely to be undertaking knowledge sourcing through in-house R\&D from competitors and public knowledge sources than other firms. Here, horizontal links to competitors may reflect the potential for horizontal alliances and joint ventures to allow cost sharing and risk reduction (Irwin and Klenow, 1996), with similar cost considerations also potentially shaping firms' desire to develop links to publicly available knowledge sources.

Firms' knowledge utilisation capacity does have some impact on their knowledge sourcing activities but the links are perhaps weaker, and less general, than might have been anticipated (Table 2). In particular, skill levels within the enterprise prove largely unimportant in shaping external knowledge sourcing, although there is some link to undertaking internal R\&D. Enterprises with a formal R\&D department were also significantly more likely to be engaged in public knowledge sourcing ${ }^{13}$. These results closely reflect the recent findings of Schmidt (2005) in his analysis of absorptive capacity in German firms. He too finds strong R\&D effects on firms' ability to absorb external knowledge but much weaker effects linked to human resources and knowledge sharing routines within the firm. Public support for R\&D, innovation and training have a positive impact on both internal $R \& D$ and public knowledge sourcing but little consistent effect on enterprises' other knowledge sourcing activities. Enterprises which received public support for product or process development were, in total, 32 per cent more likely to be engaging in in-plant $R \& D$, a result which is consistent with some previous findings (see for example, Griliches, 1995). Public support for R\&D or innovation also had a positive effect on the level of public

12 This suggestion may provide another potential motivation for US inward investment to Ireland over and above more standard accounts based on tax advantages and market access (Ruane and Görg, 1997). But see also Wrynn (1997).

${ }^{13}$ This differs from Roper et al (2006), in which formal R\&D is positively associated with all other forms of knowledge sourcing. However, this earlier analysis does not allow for the separate influence of all five sources of knowledge including in-house R\&D, thus potentially overstating the influence of a formal R\&D department on the likelihood of using other knowledge sources. 
knowledge sourcing which was increased by 6.7 per cent. Some care is necessary, however, in the interpretation of both effects given the potential for selection bias in the award of public support. Finally, market environment effects on firms' external knowledge sourcing behaviour were also weak, although the probability of engaging in R\&D in Northern Ireland was significantly lower than that in Ireland, perhaps reflecting firms' lower anticipated level of post innovation returns (Levin and Reiss, 1994).

In summary, we find strong evidence of complementarities between enterprises' knowledge sourcing activities, although these vary considerably in strength (see also Cassiman and Veugelers, 2002). Aspects of enterprises' resource base also prove important but again the relationship to each knowledge sourcing activity differs significantly. Firms' knowledge utilisation capacity is perhaps less significant than anticipated, with in-plant R\&D playing the most significant role in influencing knowledge sourcing; skill-related measures prove less useful. Locational and policy factors also prove important in the analysis reflecting the specificities of firms' operating environment in Ireland and Northern Ireland. Our findings resemble those of Schmidt (2005) for Germany in two important senses. First, our study like his emphasises the different factors which influence knowledge sourcing. Secondly, our study also emphasises in-house R\&D capacity and organisation as the key element of absorptive capacity rather than other potential contributors such as skill levels.

\subsection{Innovation}

The second link in the innovation value chain is the transformation of knowledge into product and process innovation represented by the innovation production function (equation 2). Here, we are interested in the contribution of each knowledge source to innovation as well as in the range of factors contributing to the efficiency of enterprises' knowledge transformation activity. Estimates of the innovation production function for the three innovation output measures are given in Table 3, with column (3) reporting sub-sample estimates for enterprises with non-zero innovation success. 
Despite the differences in estimation methods and dependent variables there are marked similarities between the sign patterns and significance of key variables across the innovation production function estimates. Establishment size, for example, has no impact on product innovation but is significant for process innovation. Likewise plant age has a uniformly negative effect, being significant for product innovation success and process innovation. Differences in the estimated models are reflected in Figures 2 and 3 which summarise the key marginal elasticities emerging from the innovation value chain estimation.

Knowledge sourcing of different types has, as expected, a positive impact on innovation where it is statistically significant. In-plant $R \& D$, for example, has a positive and significant effect on both product and process innovation as well as innovation success in the whole sample. Interestingly, however, in-plant R\&D has no significant effect on innovation success where the model is estimated only for the innovation sub-sample. In substantive terms this suggests that in-plant R\&D is boosting the likelihood of enterprises engaging in product innovation, but then having no significant impact on the success of that innovation activity. In fact, our estimates suggest that enterprises conducting in-plant $R \& D$ are 27.5 per cent and 11.9 per cent more likely to develop product innovation and process innovations ceteris paribus ${ }^{14}$. As we have argued elsewhere (Roper et al 2006), in conjunction with the results of the knowledge sourcing equations in Table 2 this suggests that in-house R\&D contributes to firms' innovation activity in two ways. First, through complementarities, in-house R\&D increases the likelihood that firms will engage in external knowledge sourcing, and hence the likelihood that they will be able to obtain successfully the knowledge necessary for innovation. This is an 'absorptive capacity' effect of the sort envisaged by Cohen and Levinthal (1989, 1990), and Zahra and George (2002). Second, in-house R\&D contributes directly to enterprises' knowledge stock increasing average innovation success - an 'appropriation' effect due perhaps to higher innovation

\footnotetext{
${ }^{14}$ In more methodological terms the contrast between the R\&D effects in the whole sample and sub-sample models do suggest the potential importance of sample selection bias when estimation is restricted to innovators only. In our sample this approach would have under-estimated the true effect of R\&D on increasing the extent of innovation in the population of enterprises.
} 
quality .

As expected, forward knowledge sourcing has significant positive influence on both the product innovation decision, increasing the probability of product innovation by 11.2 per cent, and innovation success by 11.1 per cent. Forward knowledge sourcing, however, has no significant process innovation effect, perhaps reflecting the stronger impact of customer-led innovation on product rather than process change (Karkkainen et al., 2001). Conversely, backward and horizontal knowledge sourcing increase the probabilities of firms' decision to engage in product and process change, but have no impact on innovation success (Figures 2 and 3). Finally, unlike the other knowledge sources, links to public knowledge sources (i.e. universities, public and industry-owned laboratories) have no direct impact on either the probability of process or product innovation, or its success (Figures 2 and 3$)^{15}$.

Other resources also prove important in shaping enterprises' innovation outputs. Size - as suggested earlier - has no impact on product innovation but does have a positive (and linear) impact on the probability of undertaking process innovation. Plant age has a negative effect on the probability that a plant will be a process innovator and also on innovation success, with the percentage of innovative sales declining by around 0.1 per cent for each year a plant ages. This is consistent with a life-cycle model of plant development, which envisages a concentration of innovative activity occurring in the first years after a plant is established, and then declining levels of innovation and increasing product maturity (Atkeson and Kehoe, 2005). Plants focussed on more routinised production also seem more likely to be undertaking innovation in both product and processes than those geared towards bespoke or one-off products. This may reflect the greater managerial sophistication of these plants, or be some aspect of economies of scale in R\&D, especially where relatively long runs of fairly settled products give rise to positive returns to process improvements coupled with product improvements. Perhaps more unexpected is the

\footnotetext{
${ }^{15}$ Public knowledge sourcing does, however, have an indirect positive effect on innovation through its complementary relationship to other types of knowledge sourcing activity (Table 1).
} 
finding that, ceteris paribus, enterprises which are part of multinational groups in Ireland and Northern Ireland are no more likely to be either product or process innovators than other firms. Access to financial resources and external (group) R\&D also prove important, with financial stringency encouraging innovation - mater atrium necessitas - and access to group R\&D increasing the probability of engaging in product innovation by 8.5 per cent, process innovation by 13 per cent and innovation success by 6.5 per cent.

Measures of firms' knowledge utilisation capacity also prove important in boosting innovation outcomes, reflecting the various dimensions of absorptive capacity emphasised by Zahra and George (2002). High quality human resources contribute strongly to both the product and process innovation decisions and innovation success (e.g. Freel, 2003; Michie and Sheehan, 2002); having a formal R\&D department also proves a significant bonus in terms of product innovation success. This latter result emphasises the point that it is not simply the presence within an enterprise of the resources needed for innovation but that their mode of organisation can also make a significant difference to their contribution to innovation.

Government support for innovation also proves important, although as indicated earlier some care is necessary in interpreting the policy implications of this result (Greene, 2005, p. 982). In particular, the coefficients on the policy support - treatment terms - reflect the combination of 'assistance' and 'selection' effects ${ }^{16}$.

\subsection{From Innovation to Productivity and Growth}

The final link in the innovation value chain is the exploitation of enterprises' product and process innovation. The main focus of interest here is the impact of the innovation indicators on business growth and productivity (i.e. value added per employee). Tables 4 and 5 report marginal effects from the estimation of growth and

\footnotetext{
${ }^{16}$ Separately identifying the selection and assistance effects requires a different estimation approach to that adopted here. See Maddala, 1973, pp. 257-290 for a general discussion of the issue and Roper and Hewitt-Dundas (2001) for an application.
} 
productivity equations with product innovation represented by innovation success and the binary product innovation decision variable respectively.

The first striking result in the performance models is the strongly significant and positive impact of both product and process innovation on business growth in both Tables 4 and 5. The implication is that, regardless of other factors, enterprises which are undertaking either product or process innovation grow faster than those which are not (Figures 2 and 3 ). The same cannot be said, however, of productivity where we find insignificant process innovation effects and, at least in the innovation success models (Table 4), negative product innovation effects. This result, which has been noted elsewhere (Freel and Robson 2004), we interpret as a disruption effect. For example, the introduction of new products to a plant may disrupt production and reduce productivity, an effect which is also suggested by the negative productivity effects of bespoke production (i.e. one-offs and small batches). Alternatively, the negative productivity effect of innovation success may be explained by a product life-cycle effect. In this scenario, newly introduced products are initially produced inefficiently with negative productivity consequences before becoming established and the focus of process innovations to improve productive efficiency.

In addition to the innovation indicators, the strength of enterprises' resource base also proves important in determining performance, although again the importance of different indicators differs somewhat between the productivity and growth models (Tables 4 and 5). Plant size, for example, has a consistent (inverted U) influence on productivity but has no significant impact on either employment or sales growth (e.g. Barkham et al., 1996; Hakim, 1989). The effects of plant age also differ, having a positive effect on productivity but consistently negative growth effects. In other words, older plants tend to have higher productivity but slower growth (Roper and Hewitt-Dundas, 2001). Being part of a multi-national group has a similar effect to that of enterprise age, positively impacting on productivity but having a negative growth effect. Unsurprisingly too, enterprises with higher capital intensity (per employee) also have higher productivity and tend also to have faster employment and sales 
growth (Tables 4 and 5). Two other factors also prove consistently important in determining growth and productivity performance. Skill levels have a consistently positive effect on both performance measures, but being located in Northern Ireland is reflected in lower productivity and slower sales and employment growth. In general terms our augmented production function estimates therefore emphasise the importance of enterprises' resource base for productivity and growth, but also suggest that innovation has a significant performance augmenting effect.

\section{Conclusion}

The key results of our estimation are summarised in Figures 2 and 3 which illustrate the innovation value chain using the product innovation decision indicator and the innovation success indicator respectively. In each case, the causal link from knowledge sourcing through innovation to business growth and productivity is clear, although the strength and sign of the different linkages varies depending somewhat on indicator choice. The implication is that in both Ireland and Northern Ireland there is evidence of a positive innovation value chain with firms' innovation activities grounded in their knowledge sourcing activity and resulting in enhanced business performance. Firms' characteristics, internal resources, and market environment, however, all play a part in shaping the strength of each of the links in the innovation value chain. In our data, for example, internal R\&D and backward knowledge sourcing have positive direct effects on both product and process innovation as well as positive complementarity effects on enterprises' other knowledge sourcing activities. Forward and horizontal knowledge sourcing have similar complementary effects with enterprises' other external knowledge sourcing activities but have a direct influence only on product innovation. Finally, enterprises public knowledge sourcing activities have no direct impact on innovation but have an indirect positive effect on innovation through their strong complementarity with other knowledge sourcing activities.

In this sense, our analysis suggests an important difference in the routes by which public knowledge sourcing on one hand, and the other types of external knowledge 
sourcing and internal knowledge sourcing on the other, contribute to innovation and hence business performance. This suggests the need for a more differentiated approach to knowledge acquired from different sources - and firms' ability to absorb knowledge from different sources - than generally characterises the innovation literature (although see Schmidt, 2005), and raises some questions about the accessibility of public knowledge generators as innovation partners. In a more specific sense it raises questions about the ability of the university network in Ireland and Northern Ireland to contribute to innovation, at least during our sample period ${ }^{17}$. Since 2000, however, and too late to have a significant impact on the current analysis, steps have been taken to strengthen commercially relevant research in universities in Ireland and Northern Ireland. In Ireland, investments under the 2000-06 National Development Plan - including Science Foundation Ireland and the Programme of Research in Third Level Institutions - have increased investment in higher education R\&D by an order of magnitude. In Northern Ireland, similarly large investments have been made in developing Centres of Research Excellence. Both may help in the longer-term to strengthen the direct contribution of the higher education sector in Ireland and Northern Ireland to innovation.

In addition to highlighting the direct and indirect routes through which enterprises' knowledge sourcing can influence innovation and business performance, the innovation value chain also highlights the enabling role of other factors in shaping enterprises' knowledge sourcing behaviour and influencing enterprises' knowledge transformation and exploitation capability. The quality of enterprises' human resources, for example, which we interpret here as an indicator of firms' knowledge utilisation capacity, influences the innovation value chain for Irish firms through three routes. First, although they have little impact on external knowledge sourcing, high quality human resources do enable internal R\&D in our sample of firms (Table 2), and through complementarity effects have a positive effect on firms' other knowledge sourcing activities. Secondly, high quality human resources contribute positively to

\footnotetext{
17 This is despite significant investment during the late-1990s in building connectivity and applied research capability (e.g. the START programme in Northern Ireland and the Programmes for Advanced Technologies (PATs) in Ireland).
} 
firms' knowledge transformation ability in both the product and process innovation production functions (Table 3). Thirdly, skill levels contribute to firms' ability to generate value from their innovation, taking strong positive coefficients in both the growth and productivity production functions (Tables 4 and 5). The structural nature of our innovation value chain analysis allows these different links to be identified explicitly.

In policy terms our innovation value chain analysis has two main implications. First, we are able to clearly identify the drivers of firm-level growth and productivity in Ireland and Northern Ireland, and in particular to highlight the complementary role of capital investment, skills, ownership and innovation. This provides a clear signal that each of these factors is important in influencing innovation and business performance both through their direct effect but also potentially through complementary effects with other innovation drivers. The innovation value chain approach also exposes the the mechanisms through which these factors influence innovation performance, providing a potential structure for the evaluation of future policy initiatives. Secondly, through the innovation value chain we are able to identify the drivers of innovation behaviour itself, emphasising the role of $R \& D$ as both a direct and indirect influence on innovation success, but also the role of other important sources of knowledge for innovation. The implication is that policy intervention to strengthen knowledge sharing may have direct benefits for innovation, but may also have indirect benefits through complementary relationships with other innovation drivers. Key here is the role of in-house $\mathrm{R} \& \mathrm{D}$ which has both direct benefits and helps to maximise the innovation benefits of other forms of knowledge sourcing.

The richness of the information in the IIP database allows the innovation value chain to be explored in considerable detail for Ireland and Northern Ireland. Our current approach has some limitations, however, which could usefully be addressed in future work. First, although based on panel data we have here adopted a pooled approach to the estimation. This reduces the temporal sophistication of our analysis and the potential to allow for lagged innovation and performance effects. For example, it may be that allowing for lagged product innovation success in the productivity models 
would suggest a positive impact rather than the negative 'disruption' effect identified in Tables 4 and 5. Future work might examine the dynamics in more detail as new survey data become available. Second, our current analysis is limited to Ireland and Northern Ireland. It would be of considerable interest to see whether the type of relationships identified here were robust across national boundaries. Third, in the modelling to date we have employed fairly simple model specifications and estimation approaches. Both could usefully be developed to allow for potential interactions between variables, for example, and to test for the potential impact of selection biases or simultaneity. Finally, there is the issue of sector-specific effects. While all of the estimations discussed above include 2-digit industry dummies to allow for sectoral variations in, for example, innovation intensity and productivity, these cannot capture all sector-specific differences. Variations might be expected between the knowledge sourcing behaviour of science-based and scale-intensive sectors, for example, with the possibility of differences in the patterns of complementarity between the different knowledge sources. Future work might profitably explore the extent and nature of such sectoral differences. 


\section{Innovation Indicators}

Innovation success - percentage of new products in sales (\%)

$15.125 \quad 22.842$

Product innovation - new or improved products in the previous three years $(0 / 1)$

0.625

0.484

Process innovation - new or improved processes in the previous three years $(0 / 1)$

\section{Knowledge Sourcing Activities}

R\&D being undertaken in the plant $(0 / 1)$

Forward knowledge linkages to clients or customers $(0 / 1)$

$0.265 \quad 0.442$

Backward knowledge linkages to suppliers or consultants $(0 / 1)$

$0.325 \quad 0.468$

Horizontal knowledge linkages to competitors or joint ventures $(0 / 1)$

$0.121 \quad 0.326$

Public knowledge linkages to universities, industry operated labs or public labs

$0.193 \quad 0.395$

\section{Firm Performance}

Labour productivity (value added per employee)

Employment growth

\section{Resources}

Employment (number)

Part of a multi-national enterprise (multinational firms) (0/1)

$114.48 \quad 315.685$

Plant age (years)

$0.32 \quad 0.466$

Capital intensity (investments on fixed assets/total employment)

Type of production in plant - mainly one-offs $(0 / 1)$

Type of production in plant - mainly large batches $(0 / 1)$

$0.192 \quad 0.394$

Innovation constraints: Shortages of finance (score)

$0.294 \quad 0.456$

Relevant R\&D being conducted in the group (R\&D in group) $(0 / 1)$

\section{Knowledge Utilisation Capacity}

Percentage of workforce with degree (\%)

Percentage of workforce with no qualifications (\%)

Formal R\&D Department in plant $(0 / 1)$

\section{Government and EU Assistance}

Government assistance on product/process innovation (0/1)

Government assistance on capital (plant/machinery) (0/1)

$0.268 \quad 0.443$

Government assistance on management training/training on process

$0.184 \quad 0.388$

development/best practice $(0 / 1)$

\section{Market Environment}

Northern Ireland plant $(0 / 1)$

Source: Irish Innovation Panel 
Table 2: Knowledge sourcing equations

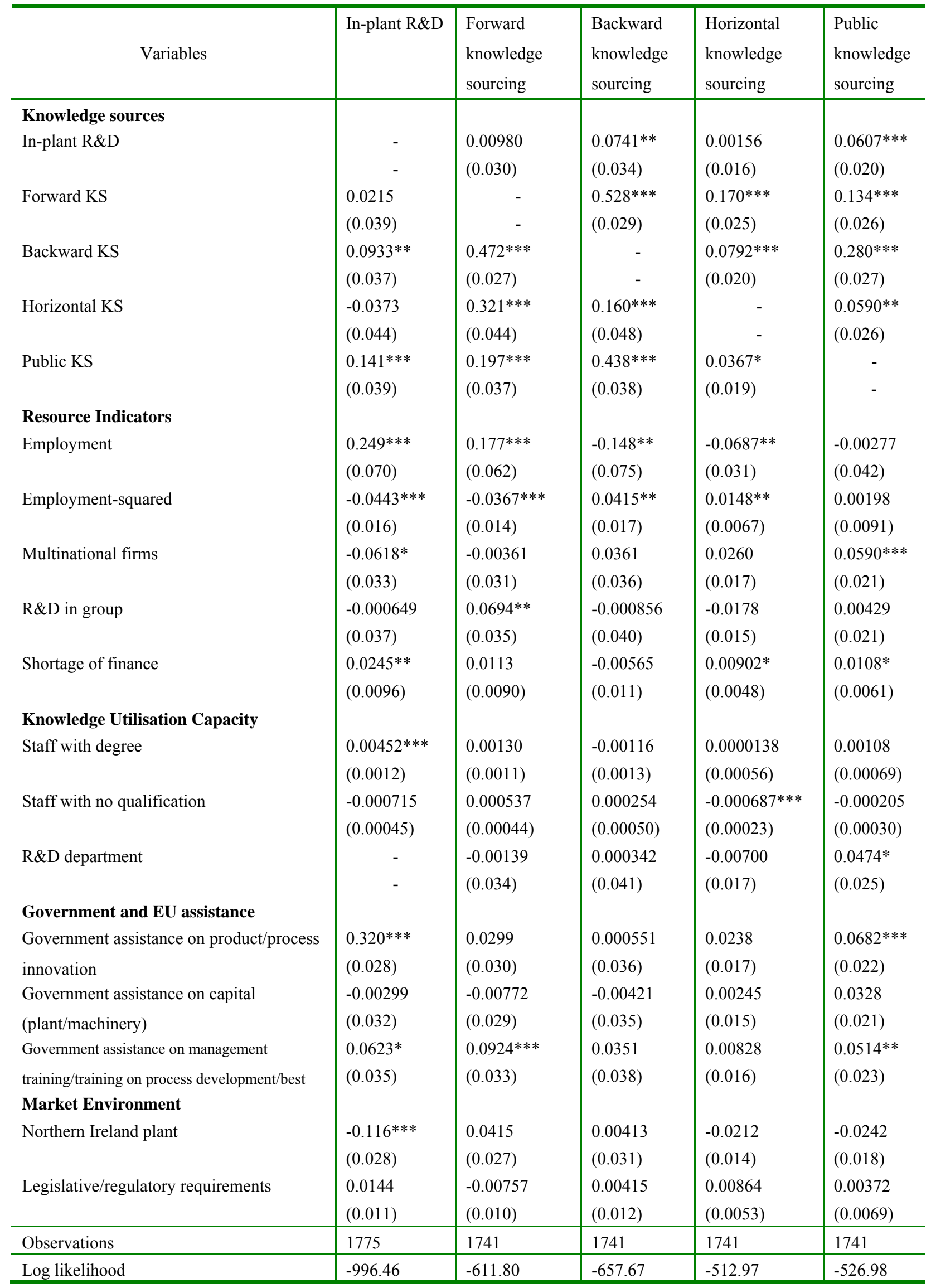

Notes: Standard errors in parentheses; ${ }^{* * *} \mathrm{p}<0.01,{ }^{* *} \mathrm{p}<0.05,{ }^{*} \mathrm{p}<0.1$. All the figures in the table are marginal effects generated from probit models. All models include industry dummies. 
Table 3: Innovation Production Functions

\begin{tabular}{|c|c|c|c|c|}
\hline & \multicolumn{3}{|c|}{ Product Innovation } & \multirow{2}{*}{$\begin{array}{l}\text { Process } \\
\text { innovation: } \\
\text { decision }\end{array}$} \\
\hline & Decision & $\begin{array}{c}\text { Success: whole } \\
\text { sample }\end{array}$ & $\begin{array}{l}\text { Success: product } \\
\text { innovator only }\end{array}$ & \\
\hline \multicolumn{5}{|l|}{ Knowledge sources } \\
\hline In-plant R\&D & $\begin{array}{c}0.275 * * * \\
(0.027)\end{array}$ & $\begin{array}{c}0.1806401 * * * \\
(0.02569)\end{array}$ & $\begin{array}{c}-0.0206291 \\
(0.27)\end{array}$ & $\begin{array}{c}0.119 * * * \\
(0.029)\end{array}$ \\
\hline Forward KS & $\begin{array}{c}0.112 * * * \\
(0.034)\end{array}$ & $\begin{array}{c}0.1109711 * * * \\
(0.03054)\end{array}$ & $\begin{array}{c}0.0551659 * * * \\
(0.007)\end{array}$ & $\begin{array}{l}0.0367 \\
(0.038)\end{array}$ \\
\hline Backward KS & $\begin{array}{c}0.0811 * * \\
(0.034)\end{array}$ & $\begin{array}{c}0.0329439 \\
(0.03065)\end{array}$ & $\begin{array}{c}-0.0189386 \\
(0.376)\end{array}$ & $\begin{array}{c}0.160 * * * \\
(0.034)\end{array}$ \\
\hline Horizontal KS & $\begin{array}{c}0.0984 * * * \\
(0.037)\end{array}$ & $\begin{array}{c}0.0402106 \\
(0.03305)\end{array}$ & $\begin{array}{c}-0.0028787 \\
(0.899)\end{array}$ & $\begin{array}{c}0.0814 * * \\
(0.041)\end{array}$ \\
\hline Public KS & $\begin{array}{l}-0.0307 \\
(0.043)\end{array}$ & $\begin{array}{c}-0.0522171 \\
(0.03325)\end{array}$ & $\begin{array}{c}-0.0241271 \\
(0.296)\end{array}$ & $\begin{array}{l}0.0142 \\
(0.042)\end{array}$ \\
\hline \multicolumn{5}{|l|}{ Resource Indicator } \\
\hline Employment & $\begin{array}{l}0.000153 \\
(0.00018)\end{array}$ & $\begin{array}{c}0.0000755 \\
(0.00007)\end{array}$ & $\begin{array}{c}0.000019 \\
(0.69)\end{array}$ & $\begin{array}{c}0.000320 * * * \\
(0.00012)\end{array}$ \\
\hline Employment-squared & $\begin{array}{l}0.00000857 \\
(0.000034)\end{array}$ & $\begin{array}{c}-0.00000142 \\
(0.000003)\end{array}$ & $\begin{array}{c}1.42 \mathrm{E}-07 \\
(0.95)\end{array}$ & $\begin{array}{l}-0.00000835 \\
(0.0000075)\end{array}$ \\
\hline Age & $\begin{array}{l}-0.000237 \\
(0.00045)\end{array}$ & $\begin{array}{c}-0.0015937 * * * \\
(0.00039)\end{array}$ & $\begin{array}{c}-0.0012434 * * * \\
(0.0002569)\end{array}$ & $\begin{array}{c}-0.000943 * * \\
(0.00043)\end{array}$ \\
\hline Multinational firms & $\begin{array}{l}0.00787 \\
(0.029)\end{array}$ & $\begin{array}{c}0.0139323 \\
(0.02648)\end{array}$ & $\begin{array}{c}0.002311 \\
(0.904)\end{array}$ & $\begin{array}{l}0.0240 \\
(0.030)\end{array}$ \\
\hline One-off production & $\begin{array}{c}-0.123 * * * \\
(0.037)\end{array}$ & $\begin{array}{c}-0.1135328 * * * \\
(0.03251)\end{array}$ & $\begin{array}{c}-0.025847 \\
(0.314)\end{array}$ & $\begin{array}{l}-0.0570 \\
(0.036)\end{array}$ \\
\hline $\mathrm{R} \& \mathrm{D}$ in group & $\begin{array}{c}0.0850 * * * \\
(0.030)\end{array}$ & $\begin{array}{c}0.0653202 * * \\
(0.02867)\end{array}$ & $\begin{array}{c}0.0107255 \\
(0.593)\end{array}$ & $\begin{array}{c}0.130 * * * \\
(0.032)\end{array}$ \\
\hline Shortage of finance & $\begin{array}{l}0.0200 * * \\
(0.0088)\end{array}$ & $\begin{array}{c}0.0263102 * * * \\
(0.00799)\end{array}$ & $\begin{array}{c}0.0135643 * * \\
(0.017)\end{array}$ & $\begin{array}{l}0.00137 \\
(0.0092)\end{array}$ \\
\hline \multicolumn{5}{|l|}{ Knowledge Utilisation Capacity } \\
\hline Staff with degree & $\begin{array}{c}0.00373 * * * \\
(0.0013)\end{array}$ & $\begin{array}{c}0.0025178 * * \\
(0.00105)\end{array}$ & $\begin{array}{c}0.0005818 \\
(0.42)\end{array}$ & $\begin{array}{c}-0.00400 * * * \\
(0.0013)\end{array}$ \\
\hline Staff with no qualification & $\begin{array}{c}0.0000404 \\
(0.00041)\end{array}$ & $\begin{array}{c}-0.0002872 \\
(0.00038)\end{array}$ & $\begin{array}{c}-0.0004358 \\
(0.112)\end{array}$ & $\begin{array}{l}0.000111 \\
(0.00043)\end{array}$ \\
\hline R\&D department & $\begin{array}{l}0.108 * * * \\
(0.035)\end{array}$ & $\begin{array}{c}0.0961436 * * * \\
(0.02927)\end{array}$ & $\begin{array}{c}0.0631407 * * * \\
(0.001)\end{array}$ & $\begin{array}{c}-0.00342 \\
(0.039)\end{array}$ \\
\hline $\begin{array}{l}\text { Government and EU assistance } \\
\text { Government assistance on product/process } \\
\text { innovation }\end{array}$ & $\begin{array}{l}0.0742 * * \\
(0.030)\end{array}$ & $\begin{array}{l}0.0342639 \\
(0.02644)\end{array}$ & $\begin{array}{c}-0.0038481 \\
(0.834)\end{array}$ & $\begin{array}{c}0.0866^{* * *} \\
(0.031)\end{array}$ \\
\hline $\begin{array}{l}\text { Government assistance on capital } \\
\text { (plant/machinery) }\end{array}$ & $\begin{array}{c}0.000572 \\
(0.029)\end{array}$ & $\begin{array}{l}0.0027234 \\
(0.02547)\end{array}$ & $\begin{array}{l}0.0014553 \\
(0.935)\end{array}$ & $\begin{array}{c}0.145 * * * \\
(0.028)\end{array}$ \\
\hline $\begin{array}{l}\text { Government assistance on management } \\
\text { training/training on process } \\
\text { development/best practice }\end{array}$ & $\begin{array}{l}0.00771 \\
(0.034)\end{array}$ & $\begin{array}{c}0.069377 * * * \\
(0.02692)\end{array}$ & $\begin{array}{c}0.041288 * * * \\
(0.018)\end{array}$ & $\begin{array}{l}0.0614 * \\
(0.033)\end{array}$ \\
\hline Market Environment & & & & \\
\hline Northern Ireland plant & $\begin{array}{c}-0.00788 \\
(0.025)\end{array}$ & $\begin{array}{c}-0.0149813 \\
(0.02358)\end{array}$ & $\begin{array}{c}-0.0153116 \\
(0.01731)\end{array}$ & $\begin{array}{c}-0.0484 * \\
(0.027)\end{array}$ \\
\hline Legislative/regulatory requirements & $\begin{array}{c}-0.0198 * * \\
(0.0098) \\
\end{array}$ & $\begin{array}{c}-0.0115106 \\
(0.00901) \\
\end{array}$ & $\begin{array}{c}-0.0026818 \\
(0.681) \\
\end{array}$ & $\begin{array}{c}0.00313 \\
(0.010) \\
\end{array}$ \\
\hline Observations & 1620 & 1544 & 1033 & 1613 \\
\hline Log likelihood & -752.84 & -553.13 & -68.57 & -882.33 \\
\hline
\end{tabular}

Notes: Standard errors in parentheses; $* * * \mathrm{p}<0.01,{ }^{* *} \mathrm{p}<0.05,{ }^{*} \mathrm{p}<0.1$; All the figures in the table are marginal effects generated from Probit/Tobit models; All models include industry dummies. 
Table 4: Augmented Production Function Estimates - Product Innovation Success

\begin{tabular}{|c|c|c|c|c|c|c|}
\hline & \multicolumn{3}{|c|}{ Outlier Robust Regressions } & \multicolumn{3}{|c|}{ Median Regressions } \\
\hline & Productivity & Sales growth & Emp growth & Productivity & Sales growth & Emp growth \\
\hline \multicolumn{7}{|l|}{ Innovation activities } \\
\hline Innovation success & $\begin{array}{l}-0.302 * * * \\
(0.067)\end{array}$ & $\begin{array}{l}16.72 * * * \\
(2.59)\end{array}$ & $\begin{array}{l}6.747 * * * \\
(1.75)\end{array}$ & $\begin{array}{l}-0.285^{* * *} \\
(0.071)\end{array}$ & $\begin{array}{l}28.52 * * * \\
(2.60)\end{array}$ & $\begin{array}{l}19.15^{* * *} \\
(1.87)\end{array}$ \\
\hline Process innovation & $\begin{array}{l}0.0151 \\
(0.030)\end{array}$ & $\begin{array}{l}5.256^{* * *} \\
(1.14)\end{array}$ & $\begin{array}{l}3.012 * * * \\
(0.78)\end{array}$ & $\begin{array}{l}0.0212 \\
(0.032)\end{array}$ & $\begin{array}{l}5.521 * * * \\
(1.15)\end{array}$ & $\begin{array}{l}2.322 * * * \\
(0.83)\end{array}$ \\
\hline \multicolumn{7}{|l|}{ Firm Characteristics } \\
\hline Employment & $\begin{array}{l}0.000389 * * * \\
(0.00015)\end{array}$ & $\begin{array}{l}-0.000609 \\
(0.0053)\end{array}$ & $\begin{array}{l}0.00151 \\
(0.0026)\end{array}$ & $\begin{array}{l}0.000348^{* * * *} \\
(0.00011)\end{array}$ & $\begin{array}{l}-0.00354 \\
(0.0052)\end{array}$ & $\begin{array}{l}0.00306 \\
(0.0026)\end{array}$ \\
\hline Employment-squared & $\begin{array}{l}-0.0000269 * \\
(0.000014)\end{array}$ & $\begin{array}{l}0.0000372 \\
(0.00045)\end{array}$ & $\begin{array}{l}-0.0000677 \\
(0.00013)\end{array}$ & $\begin{array}{l}-0.0000117 * * * \\
(0.0000037)\end{array}$ & $\begin{array}{l}0.000144 \\
(0.00039)\end{array}$ & $\begin{array}{l}-0.000134 \\
(0.000092)\end{array}$ \\
\hline Age & $\begin{array}{l}0.00187 * * * \\
(0.00048)\end{array}$ & $\begin{array}{l}-0.0892 * * * \\
(0.018)\end{array}$ & $\begin{array}{l}-0.0836^{* * *} \\
(0.012)\end{array}$ & $\begin{array}{l}0.00140 * * * \\
(0.00052)\end{array}$ & $\begin{array}{l}-0.0795 * * * \\
(0.019)\end{array}$ & $\begin{array}{l}-0.0681^{* * *} \\
(0.013)\end{array}$ \\
\hline Capital intensity & $\begin{array}{l}0.0179 * * * \\
(0.0014)\end{array}$ & $\begin{array}{l}0.331 * * * \\
(0.033)\end{array}$ & $\begin{array}{l}0.0308 \\
(0.022)\end{array}$ & $\begin{array}{l}0.0136^{* * *} \\
(0.0010)\end{array}$ & $\begin{array}{l}0.209 * * * \\
(0.034)\end{array}$ & $\begin{array}{l}0.150 * * * \\
(0.024)\end{array}$ \\
\hline Multinational firms & $\begin{array}{l}0.334 * * * \\
(0.032)\end{array}$ & $\begin{array}{l}-7.013^{* * * *} \\
(1.22)\end{array}$ & $\begin{array}{l}-4.392 * * * \\
(0.82)\end{array}$ & $\begin{array}{l}0.350 * * * \\
(0.033)\end{array}$ & $\begin{array}{l}-5.583^{* * * *} \\
(1.22)\end{array}$ & $\begin{array}{l}-5.588^{* * * *} \\
(0.87)\end{array}$ \\
\hline One-off production & $\begin{array}{l}-0.0724 * \\
(0.039)\end{array}$ & $\begin{array}{l}0.130 \\
(1.50)\end{array}$ & $\begin{array}{l}0.454 \\
(1.02)\end{array}$ & $\begin{array}{l}-0.0870 * * \\
(0.041)\end{array}$ & $\begin{array}{l}3.142^{* *} \\
(1.51)\end{array}$ & $\begin{array}{l}0.526 \\
(1.09)\end{array}$ \\
\hline Small batch production & $\begin{array}{l}-0.0726^{* *} \\
(0.028)\end{array}$ & $\begin{array}{l}-0.464 \\
(1.10)\end{array}$ & $\begin{array}{l}0.297 \\
(0.75)\end{array}$ & $\begin{array}{l}-0.0767 * * \\
(0.030)\end{array}$ & $\begin{array}{l}0.192 \\
(1.11)\end{array}$ & $\begin{array}{l}-0.224 \\
(0.80)\end{array}$ \\
\hline Large batch production & $\begin{array}{l}0.0136 \\
(0.031)\end{array}$ & $\begin{array}{l}-1.401 \\
(1.20)\end{array}$ & $\begin{array}{l}-0.0733 \\
(0.82)\end{array}$ & $\begin{array}{l}0.0162 \\
(0.033)\end{array}$ & $\begin{array}{l}-1.087 \\
(1.21)\end{array}$ & $\begin{array}{l}-0.212 \\
(0.87)\end{array}$ \\
\hline \multicolumn{7}{|l|}{ Knowledge Utilisation } \\
\hline$R \& D$ department & $\begin{array}{l}0.0359 \\
(0.037)\end{array}$ & $\begin{array}{l}2.561^{*} \\
(1.43)\end{array}$ & $\begin{array}{l}1.899^{* *} \\
(0.96)\end{array}$ & $\begin{array}{l}0.0327 \\
(0.040)\end{array}$ & $\begin{array}{l}0.932 \\
(1.44)\end{array}$ & $\begin{array}{l}0.971 \\
(1.03)\end{array}$ \\
\hline Staff with degree & $\begin{array}{l}0.0122 * * * \\
(0.0015)\end{array}$ & $\begin{array}{l}0.236^{* * *} \\
(0.058)\end{array}$ & $\begin{array}{l}0.126^{* * *} \\
(0.040)\end{array}$ & $\begin{array}{l}0.0141^{* * *} \\
(0.0016)\end{array}$ & $\begin{array}{l}0.358 * * * \\
(0.059)\end{array}$ & $\begin{array}{l}0.181 * * * \\
(0.042)\end{array}$ \\
\hline Staff with no qualification & $\begin{array}{l}-0.000704 \\
(0.00047)\end{array}$ & $\begin{array}{l}0.0114 \\
(0.018)\end{array}$ & $\begin{array}{l}0.00429 \\
(0.012)\end{array}$ & $\begin{array}{l}-0.000623 \\
(0.00050)\end{array}$ & $\begin{array}{l}0.0232 \\
(0.018)\end{array}$ & $\begin{array}{l}0.00528 \\
(0.013)\end{array}$ \\
\hline \multicolumn{7}{|l|}{ Market Environment } \\
\hline Northern Ireland plant & $\begin{array}{l}-0.121^{* * *} \\
(0.028)\end{array}$ & $\begin{array}{l}-2.866^{* * *} \\
(1.10)\end{array}$ & $\begin{array}{l}-1.991^{* * * *} \\
(0.75)\end{array}$ & $\begin{array}{l}-0.117^{* * *} \\
(0.030)\end{array}$ & $\begin{array}{l}-3.549 * * * \\
(1.11)\end{array}$ & $\begin{array}{l}-1.689^{* * *} \\
(0.80)\end{array}$ \\
\hline Observations & 1681 & 1674 & 1677 & 1683 & 1675 & 1677 \\
\hline
\end{tabular}

Notes: Standard errors in parentheses; ${ }^{* * *} \mathrm{p}<0.01,{ }^{* *} \mathrm{p}<0.05,{ }^{*} \mathrm{p}<0.1$. All models include industry dummies. 
Table 5: Augmented Production Function - Product Innovation Decision Indicator

\begin{tabular}{|c|c|c|c|c|c|c|}
\hline & \multicolumn{3}{|c|}{ Outlier Robust Regressions } & \multicolumn{3}{|c|}{ Median Regressions } \\
\hline & Productivity & Sales growth & Emp growth & Productivity & Sales growth & Emp growth \\
\hline \multicolumn{7}{|l|}{ Innovation activities } \\
\hline \multirow[t]{2}{*}{ Product innovation } & 0.0106 & $3.657 * * *$ & 1.017 & -0.00711 & $4.235^{* * *}$ & $2.191 * *$ \\
\hline & $(0.031)$ & $(1.22)$ & $(0.84)$ & $(0.031)$ & $(1.50)$ & $(0.90)$ \\
\hline \multirow[t]{2}{*}{ Process innovation } & 0.00769 & $4.863^{* * *}$ & $3.153 * * *$ & 0.00800 & $6.104 * * *$ & $3.068 * * *$ \\
\hline & $(0.030)$ & $(1.15)$ & $(0.79)$ & $(0.029)$ & $(1.42)$ & $(0.85)$ \\
\hline \multicolumn{7}{|l|}{ Firm Characteristics } \\
\hline \multirow[t]{2}{*}{ Employment } & $0.000377 * *$ & -0.00157 & -0.000666 & $0.000299 * * *$ & -0.00555 & 0.000000255 \\
\hline & $(0.00015)$ & $(0.0053)$ & $(0.0034)$ & $(0.00010)$ & $(0.0063)$ & $(0.0026)$ \\
\hline \multirow{2}{*}{ Employment-squared } & $-0.0000248^{*}$ & 0.000103 & 0.000135 & $-0.0000101 * * *$ & 0.000333 & -0.0000412 \\
\hline & $(0.000014)$ & $(0.00045)$ & $(0.00026)$ & $(0.0000033)$ & $(0.00048)$ & $(0.000094)$ \\
\hline \multirow[t]{2}{*}{ Age } & $0.00205^{* * *}$ & $-0.0942 * * *$ & $-0.0874 * * *$ & $0.00145^{* * *}$ & $-0.0869 * * *$ & $-0.0726^{* * *}$ \\
\hline & $(0.00047)$ & $(0.018)$ & $(0.012)$ & $(0.00045)$ & $(0.022)$ & $(0.013)$ \\
\hline \multirow[t]{2}{*}{ Capital intensity } & $0.0167 * * *$ & $0.296 * * *$ & $0.0375 *$ & $0.0146^{* * *}$ & $0.195 * * *$ & $0.164 * * *$ \\
\hline & $(0.0013)$ & $(0.033)$ & $(0.022)$ & $(0.00093)$ & $(0.041)$ & $(0.024)$ \\
\hline \multirow[t]{2}{*}{ Multinational firms } & $0.330 * * *$ & $-6.916^{* * *}$ & $-4.022 * * *$ & $0.351 * * *$ & $-5.593 * * *$ & $-5.143 * * *$ \\
\hline & $(0.031)$ & $(1.20)$ & $(0.82)$ & $(0.030)$ & $(1.48)$ & $(0.87)$ \\
\hline \multirow[t]{2}{*}{ One-off production } & -0.0590 & 0.441 & 0.694 & -0.0562 & 1.409 & 1.024 \\
\hline & $(0.038)$ & $(1.48)$ & $(1.01)$ & $(0.037)$ & $(1.82)$ & $(1.09)$ \\
\hline \multirow[t]{2}{*}{ Small batch production } & $-0.0812 * * *$ & -0.0867 & 0.459 & $-0.0742 * * *$ & 1.381 & -0.192 \\
\hline & $(0.028)$ & $(1.09)$ & $(0.75)$ & $(0.027)$ & $(1.34)$ & $(0.80)$ \\
\hline \multirow[t]{2}{*}{ Large batch production } & 0.00975 & -1.341 & -0.151 & 0.0134 & -1.043 & 0.123 \\
\hline & $(0.030)$ & $(1.18)$ & $(0.81)$ & $(0.030)$ & $(1.46)$ & $(0.87)$ \\
\hline \multicolumn{7}{|l|}{ Knowledge Utilisation } \\
\hline \multirow[t]{2}{*}{ R\&D department } & -0.000487 & $2.975^{* *}$ & $2.361 * *$ & 0.0256 & $4.187 * *$ & $3.179 * * *$ \\
\hline & $(0.036)$ & $(1.40)$ & $(0.95)$ & $(0.035)$ & $(1.72)$ & $(1.02)$ \\
\hline \multirow[t]{2}{*}{ Staff with degree } & $0.0113 * * *$ & $0.221 * * *$ & $0.107 * * *$ & $0.0123 * * *$ & $0.389 * * *$ & $0.171 * * *$ \\
\hline & $(0.0014)$ & $(0.055)$ & $(0.038)$ & $(0.0014)$ & $(0.068)$ & $(0.040)$ \\
\hline \multirow[t]{2}{*}{ Staff with no qualification } & -0.000566 & 0.0136 & 0.00777 & -0.000536 & 0.00568 & 0.00471 \\
\hline & $(0.00046)$ & $(0.018)$ & $(0.012)$ & $(0.00045)$ & $(0.022)$ & $(0.013)$ \\
\hline \multicolumn{7}{|l|}{ Market Environment } \\
\hline \multirow[t]{2}{*}{ Northern Ireland plant } & $-0.118^{* * *}$ & $-3.060 * * *$ & $-1.970 * * *$ & $-0.0911 * * *$ & $-3.234 * *$ & -1.323 \\
\hline & $(0.028)$ & (1.09) & $(0.75)$ & $(0.027)$ & $(1.34)$ & $(0.80)$ \\
\hline Observations & 1751 & 1746 & 1747 & 1753 & 1747 & 1748 \\
\hline
\end{tabular}

Notes: Standard errors in parentheses; $* * * \mathrm{p}<0.01, * * \mathrm{p}<0.05, * \mathrm{p}<0.1$. All models include industry dummies. 
Figure 1: Significant complementarities between firms' knowledge sourcing activities

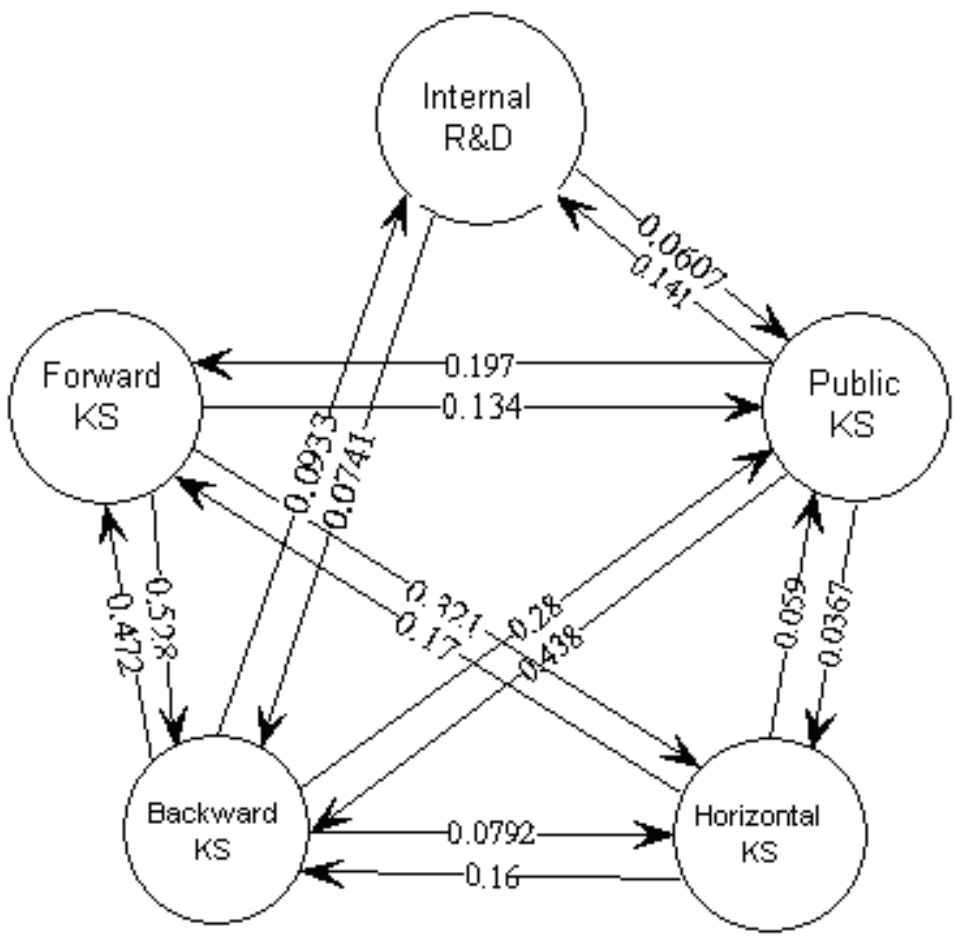

Note: The figures in the chart are marginal probabilities estimated in knowledge sourcing equations (reported in Table 2). 
Figure 2: The Innovation Value Chain - Product Innovation Success

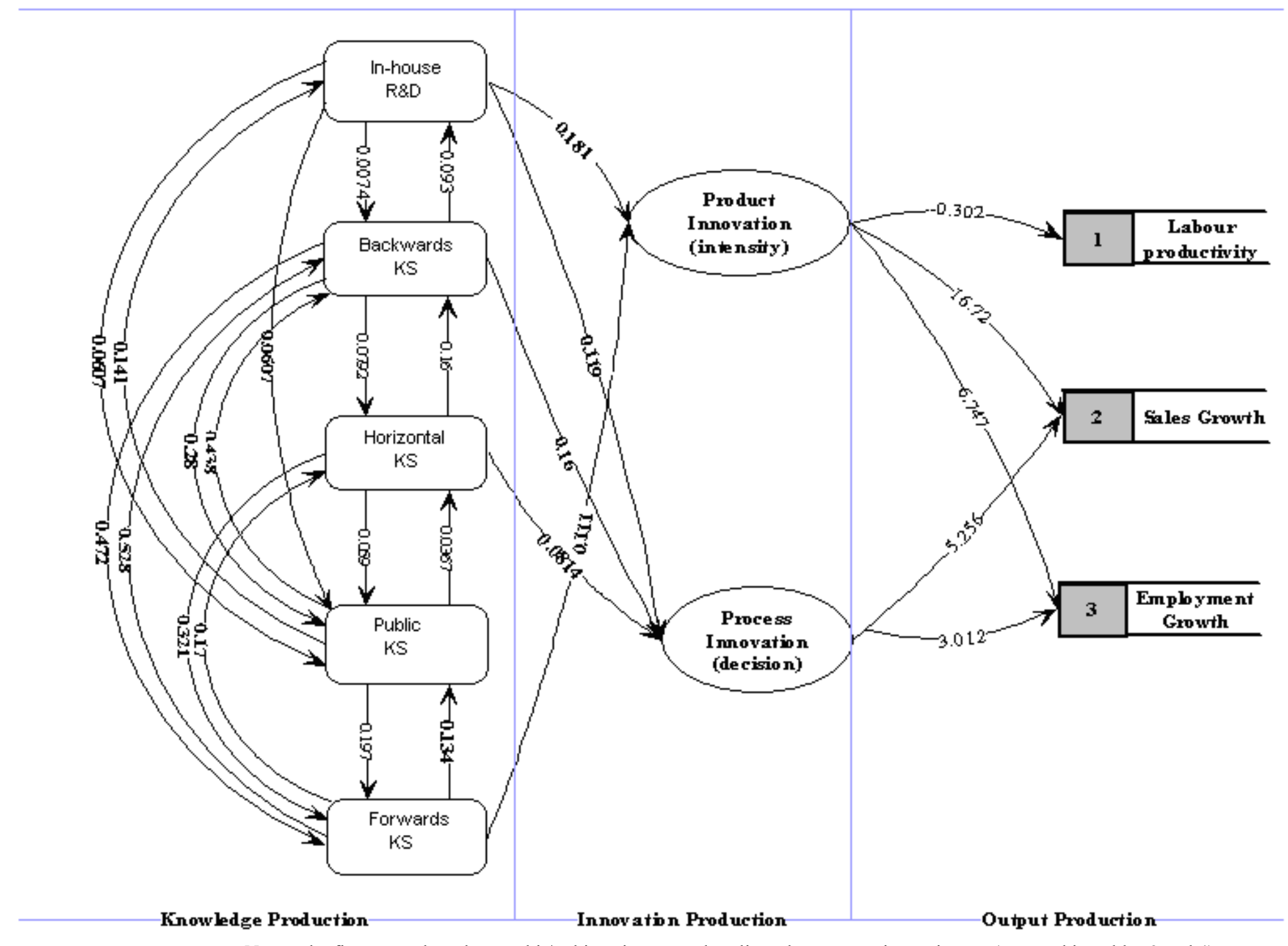

Note: The figures are based on probit/Tobit estimates and outlier robust regression estimates (reported in Tables 3 and 4). 
Figure 3: The Innovation Value Chain - Product Innovation Decision

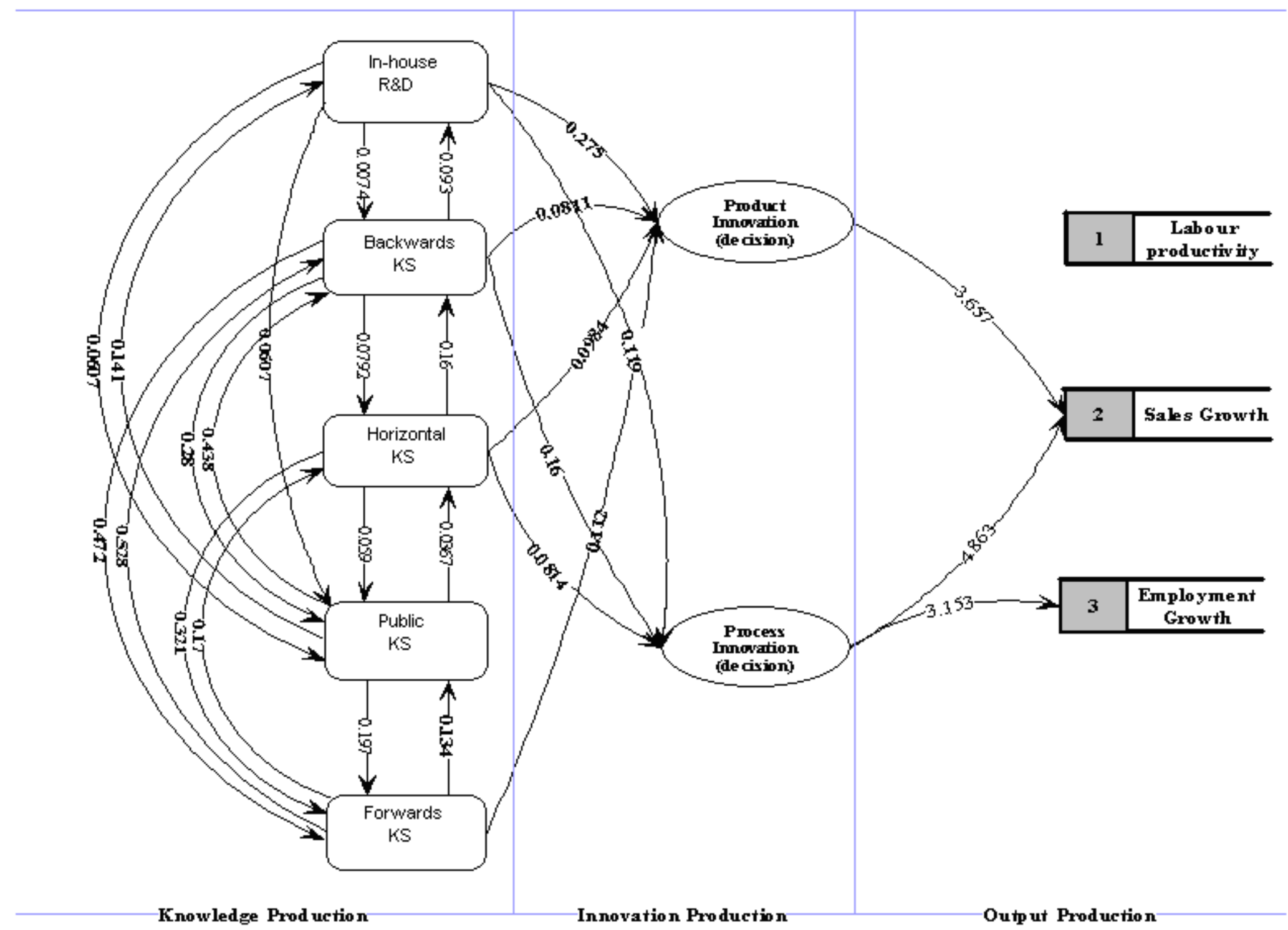

Note: The figures are based on probit/Tobit estimates and outlier robust regression estimates (reported in Tables 3 and 5). 


\section{References}

Anselin L, Varga A, Acs Z (1997) 'Local geographic spillovers between university research and high technology innovations' Journal of Urban Economics, 42, 422-448.

Anselin L, Varga A, Acs Z (2000) 'Geographic and sectoral characteristics of academic knowledge externalities', Papers in Regional Science, 79, 435-443.

Atkeson and Kehoe, (2005), 'Modeling and Measuring Organization Capital', Journal of Political Economy, 113, 1026-1053

Barkham, R, Gudgin, G, Hart, M and Hanvey, E (1996) The Determinants of Small Firm Growth: an inter-regional study in the UK 1986-90, Jessica Kingsley: London

Buckley, P J and Carter, M J (1999) 'Managing Cross Border Complementary Knowledge', International Studies of Management and Change, 29, 1, 80-104.

Beugelsdijck S and Cornet M (2001) 'How far do they reach? The localisation of industrial and academic spillovers in the Netherlands', CentER discussion paper 2001-47.

Buisseret, T J Cameron, H M and Georgiou, L (1995) 'What Difference Does It Make? Additionality in the Public Support of R\&D in Large Firms?', Evaluation of Research and Innovation, 10, 4-6, 587-600.

Cassiman, B and Veugelers, R (2002), 'R\&D cooperation and spillovers: some empirical evidence from Belgium', American Economic Review, 92, 1169-1184.

Caves, R. E. (1998), 'Industrial Organization and New Findings and the Turnover and Mobility of Firms', Journal of Economic Literature, 36, 1947-82

Cohen, W.M., Levinthal, D.A. (1989) 'Innovation and learning: the two faces of R\&D'. Economic Journal, 99, 569-596.

Cohen, W.M., Levinthal, D.A. (1990) 'Absorptive capacity: a new perspective of learning and innovation' Administrative Science Quarterly, 35, 128-152.

Cosh, AD; Hughes, A; Lee, P and Pudney, S (1997) "Semi-Parametric Estimation of the Company Size-Growth Relationship". In Begg, I and Henry, S B G (eds) Applied Economics and Public Policy, Cambridge University Press.

Crépon, B., Duguet, E., and J. Mairesse (1998) 'Research, Innovation and Productivity: An econometric analysis at the firm level', Economics of Inovation and New Technology, 7, 115-158. 
Driffield, N and Love J H (2005) 'Who gains from whom? Spillovers, competition and technology sourcing in the foreign-owned sector of UK manufacturing', Scottish Journal of Political Economy, 52, 663-686.

Du J, Love J H and Roper S (2007) 'The innovation decision: an economic analysis', Technovation, 27, 766-773.

Finegold D and Wagner K (1998) 'The Search for Flexibility: Skills and Workplace Innovation in the German Pump Industry', British Journal of Industrial Relations, 36, 469-487.

Foss, N (2004) Resources, Firms and Strategies, Oxford University Press.

Freel, M S (2005) 'Patterns of innovation and skills in small firms', Technovation, 25, 123-134.

Freel M S and Robson, P J A (2004) 'Small firm innovation, growth and performance Evidence from Scotland and northern England', International Small Business Journal, 22, 561-575.

Geroski, P. A., (1990) 'Innovation, Technological Opportunities, and Market Structure', Oxford Econonomic Papers, 42, 586-602

Geroski P, Machin S, Van Reenen J (1993) 'The Profitability of Innovating Firms', Rand Journal of Economics, 24, 198-211.

Greene, W.H. (2005), Econometric Analysis (5 ${ }^{\text {th }}$ ed.). Prentice-Hall, New Jersey.

Griffith, R Redding, S and Van Reenan, J (2003) 'R\&D and Absorptive Capacity: Theory and Empirical Evidence', Scandinavian Journal of Economics, 105, 99-118.

Griliches, Z (1992) 'The Search for Research-And-Development Spillovers', Scandinavian Journal of Economics, 94, S29-S47.

Griliches, Z. (1995), "R\&D and Productivity: Econometric Results and Measurement Issues", in P. Stoneman (ed.), Handbook of the Economics of Innovation and Technological Change, Blackwell, Oxford, 52-89.

Guellec D and van Pottelsberghe B (2004) 'From R\&D to productivity growth: do the institutional settings and the source of funds matter?' Oxford Bulletin of Economics and Statistics, 66, 353-378.

Hakim, C (1989) 'Identifying Fast Growth Small Firms’, Employment Gazette, January, 29-41.

Harris, R. I. D. and M. Trainor (1995) 'Innovation and R\&D in Northern Ireland Manufacuring: A Schumpeterian Approach', Regional Studies, 29, 593-604 
Heckman, J (1979) 'Sample Selection Bias as a specification error', Econometrica, 47, 153-161.

Hemphill, T A (2003) 'Cooperative Strategy, Technology Innovation and Product Development in Industrial Companies’, International Journal of Production Economics, 69, 169-76.

Horn, Paul M (2005) 'The Changing Nature of Innovation', Research Technology Management, 48, 28-33.

Iansiti, M and Levien, R (2004) The Keystone Advantage, Harvard Business School Press, Cambridge, Mass.

Irwin, DA and Klenow, P J (1996) 'High-Tech R\&D Subsidies - Estimating the Effects of Sematech', Journal of International Economics, 40, 323-344.

Joshi, A W and Sharma, S (2004) 'Customer Knowledge Development: Antecedents and Impact on New Product Performance', Journal of Marketing, 68, 47-59.

Karkkainen, H Piippo, P Tuominen, M (2001) 'Ten Tools for Customer-Driven Product Development in Industrial Companies', The International Journal of Production Economics, 69, 161-176.

Kim, L (1995) 'Absorptive capacity, co-operation, and knowledge creation: Samsung's leapfrogging in semiconductors', in Nonaka, I and Nishiguchi, T (eds), Knowledge Emergence - Social, Technical, and Evolutionary Dimensions of Knowledge Creation, Oxford University Press: Oxford, 270-286.

Klette T. J. and F. Johansen (1998), 'Accumulation of R\&D Capital and Dynamic Firm Performance: a not-so-Fixed Effect Model', Annales de Economie et de Statistique, 49/50, $389-419$

Klette T J, Moen J, Griliches Z (2000) 'Do subsidies to commercial R\&D reduce market failures? Microeconometric evaluation studies', Research Policy, 29, 471-495.

Koenker, R. and G. Bassett (1978), 'Regression quantiles', Econometrica, 46, 33-50

Levin, R. and P. Reiss (1984), 'Tests of a Schumpeterian Model of R\&D and Market Structure', in Z. Griliches, ed., R\&D, Patents, and Productivities, Chicago: University of Chicago Press

Link, A N Paton, D and Siegel, D S (2005) 'An Econometric Analysis of Trends in Research Joint Venture Activty’, Managerial and Decision Economics, 26, 149-158.

Lööf, H and Heshmati, A (2001) 'On the Relationship Between Innovation and Performance: A Sensitivity Analysis', SSE/EFI Working Paper No 446, Stockholm School of Economics 
Lööf, H. and A. Heshmati (2002), 'Knowledge capital and performance heterogeneity: A firm level innovation study', International Journal of Production Economics, 76, 61-85.

Love, J H and Roper, S (2001) 'Location and network effects on innovation success: evidence for UK, German and Irish manufacturing plants”, Research Policy, 30, 643-661.

Love J H, Roper S (1999) 'The determinants of innovation: R \& D, technology transfer and networking effects', Review Of Industrial Organization, 15, 43-64.

Love J H, Roper S and Mangiarotti G (2006) 'Organizing Innovation: Complementarities Between Cross-Functional Teams', Aston Business School Research Paper 0602, Birmingham.

Maddala, G (1973) 'Limited Dependent and Qualitative Variables in Econometrics', Cambridge University Press, New York.

Meehan, E. (2000) ‘Britain’s Irish Question: Britain’s European Question?: British- Irish relations in the context of the European Union and the Belfast Agreement', Review of International Studies, 26, 83-97.

Michie J, Sheehan M (2003) 'Labour market deregulation, 'flexibility' and innovation', Cambridge Journal of Economics, 27, 123-143.

Nelson, R R and Winter, S G (1982) An Evolutionary Theory of Economic Change, Harvard University Press, Cambridge, Mass.

O'Malley, E Roper, S and Hewitt-Dundas, N (2008) 'High growth and innovation with low R\&D: Ireland', in C. Edquist and L.Hommen (eds.), Small Country Innovation System: Globalization, Change and Policy in Asia and Europe, Edward Elgar.

Pittaway, L Robertson, M Munir, K Denyer, D and Neely, A (2004) 'Networking and Innovation: A Systematic Review of the Evidence', International Journal of Management Reviews, 5/6, 3/4, 137-168.

Roper, S and Anderson, J (2000) 'Innovation and E-Commerce - A Cross-Border Comparison of Irish Manufacturing Plants', NIERC Research Report 17, Belfast.

Roper S, Ashcroft B, Love J H, Dunlop S, Hofmann H, Vogler-Ludwig K, (1996) 'Product Innovation and Development in UK, German and Irish Manufacturing', Queen's University of Belfast/University of Strathclyde/ifo Institut,

Roper S, Du J and Love, J H (2006) 'Knowledge sourcing and innovation’, Aston Business School Research Paper 0605, Birmingham.

Roper, S and Hewitt-Dundas, N (1998) 'Benchmarking Company Profitability and Growth: 
Some Measurement Issues for Small Firms in Ireland', Economic and Social Review, 29, 201-208.

Roper S, Hewitt-Dundas N (2001) 'Grant assistance and small firm development in Northern Ireland and the Republic of Ireland', Scottish Journal of Political Economy, 48, 99-117.

Roper, S and Hewitt-Dundas, N (2005) 'Measuring the Impact of Grant Support for Innovation: Panel Data Evidence for Irish Firms’, European Regional Science Association, Amsterdam, August 2005.

Roper, S Hewitt-Dundas, N and Love, J H (2004) 'An Ex Ante Evaluation Framework for the Regional Benefits of Publicly Supported R\&D Projects', Research Policy, 33, 487-509.

Roper S and Love, J H (2005) 'Innovation Success and Business Performance - An All-Island Analysis', All Island Business Model Research Report, InterTradeIreland, July 2005.

Roper, S and Love, J H (2006) 'Innovation and Regional Absorptive Capacity: the Labour Market Dimension', Annals of Regional Science, 40, 437-447.

Rousseeuw, P J and Leroy, A M (1987) Robust Regression and Outlier Detection, John Wiley and Sons, New York.

Ruane, F and Görg, H (1997), 'The Impact of Foreign Direct Investment on Sectoral Adjustment in the Irish Economy'. National Institute Economic Review, 160, 76-86.

Schmidt, T (2005) 'Absorptive Capacity - One Size Fits All? A Firm-level Analysis of Absorptive Capacity for Different Kinds of Knowledge', ZEW Discussion Paper, 05-72.

Shelanski, H A and Klein, P G (1995) 'Empirical research in transaction cost economics: a review and assessment', Journal of Law, Economics and Organization, 11, 335-361.

Smith, D J and Tranfield, D (2005) 'Talented suppliers? Strategic change and innovation in the UK aerospace industry', $R \& D$ Management, 35, 37-49.

Trajtenberg, M (2001) 'Innovation in Israel 1968-1997: a comparative analysis using patent data', Research Policy, 30, 363-389.

Veugelers, R and Cassiman, B (1999) 'Make and buy in innovation strtegies: evidence from Belgian manufacturing firms', Research Policy, 28, 63-80.

Wrynn J (1997) 'Foreign Direct Investment to a Peripheral Country - The Case of Ireland' in Fynes, B and Ennis, S (eds) Competing From the Periphery, Oaktree Press, Dublin.

Zahra S A and George G (2002) 'Absorptive capacity: a review, re-conceptualization, and extension', Academy of Management Review, 27, 185-203. 